\title{
SUSTAINABLE ENTREPRENEURSHIP: AN APPROACH FROM BIBLIOMETRIC ANALYSIS
}

\author{
Ismael MOYA-CLEMENTE (D)1, Gabriela RIBES-GINER (D)1, \\ Joana Carolina CHAVES-VARGAS 1 1, $2^{*}$ \\ ${ }^{1}$ Faculty of Business Administration and Management, \\ Universitat Politècnica de València, València, Spain \\ ${ }^{2}$ Faculty of Economics and Business, La Gran Colombia University, Bogotá, Colombia \\ Received 05 December 2019; accepted 05 October 2020
}

\begin{abstract}
Researchs on issues of Sustainable Entrepreneurship are gaining traction in recent years, with this trend being aligned to the achievement of sustainable development goals set by the UN in 2030. The purpose of this paper is to carry out a bibliometric analysis on research on the subject of sustainable entrepreneurship. The information gathered is extracted from the main collection of the Web of Science (WoS) database since 1999 up to December 2019. Nvivo and VOSviwer software are used to perform initial analysis and citation analysis, co-citations, bibliographic coupling, coauthoring, among others. This study presents advances associated with the main authors, journals and countries, the general and annual citation structure and the development of this field. The results show that the publication trend increases from 2015 onwards, however 2018 and 2019 have seen the greatest production of articles. In relation to the most influential countries, the Netherlands, the United States, Germany, England and Spain are the most representative. It was also found that the most influential journals are the Journal of Cleaner Production and Sustainability. The main contribution is to show the evolution of this topic, so that researchers can use it in their theoretical frameworks and research.
\end{abstract}

Keywords: bibliometric analysis, sustainable entrepreneurship, sustainable start-up, sustainable innovation, co-citation, bibliographic coupling.

JEL Classification: M00, M13, L26.

\section{Introduction}

Literature research on sustainable entrepreneurship has had different approaches (Fichter \& Tiemann, 2020; Halberstadt et al., 2019; Terán-Yépez et al., 2020). It has focused on issues related to environment or ecology (Boons \& Lüdeke-Freund, 2013; Dean \& McMullen, 2007), leading to the use of terms such as eco-entrepreneurship (Rodgers, 2010), understood as entrepreneurs who have an environmental perspective (Schaltegger, 2014, p. 47), that is,

*Corresponding author. E-mails: jcchavesv@unal.edu.co; joachava@doctor.upv.es

Copyright (c) 2021 The Author(s). Published by Vilnius Gediminas Technical University

This is an Open Access article distributed under the terms of the Creative Commons Attribution License (http://creativecommons. org/licenses/by/4.0/), which permits unrestricted use, distribution, and reproduction in any medium, provided the original author and source are credited. 
a green perspective (Demirel et al., 2019; Gast et al., 2017). It has also been related to social areas, known as social entrepreneurship (Betáková et al., 2020; Schaltegger \& Wagner, 2011), among other it is defined as an individual with innovative solutions to respond to society's problems (Neck et al., 2009). Research has also been related to sustainable development and the triple botton line (Terán-Yépez et al., 2020).

Schaltegger and Wagner state that sustainable entrepreneurship "is in essence the realization of sustainability innovations aimed at the mass market and providing benefit to the larger part of society" (Schaltegger \& Wagner, 2011, p. 225). The above definition leads us to address the term "sustainable innovations". According to Boons there is no single definition for sustainable innovation, while it is also associated with the term eco-innovation, Boons suggests sustainable innovation as "Innovation that improves the performance of sustainability” (Boons \& Lüdeke-Freund, 2013, p. 2), taking into account ecological, economic and social issues. However, Varadarajan mentions that there are three types of sustainable innovations; one associated with the decrease in the use of resources; another related to the innovation of elimination of the use of resources and, finally; the innovation of replacement of the use of resources (Varadarajan, 2017, p. 8). Another definition is "the integration of conservation and development to ensure that modifications to the planet do indeed secure the survival and well-being of all people" (Albort-Morant et al., 2017, p. 2).

Another vision of sustainable entrepreneurship is that "is focused on the preservation of nature, life support, and community in the pursuit of perceived opportunities to bring into existence future products, processes, and services for gain, where gain is broadly construed to include economic and non-economic gains to individuals, the economy, and society" (Muñoz \& Cohen, 2018, p. 304). In the same way, Cohen and Winn (Cohen \& Winn, 2007) define it as the review of how opportunities to create goods and services are discovered and with what economic, psychological, social and environmental consequences. In this same sense, Belz and Binder (Belz \& Binder, 2017, p. 2) believe that sustainable entrepreneurship is to recognise, develop and take advantage of opportunities by individuals to create future goods and services with social, economic and ecological benefits. Likewise, the main idea of sustainable entrepreneurship is that the activities carried out by entrepreneurs must not undermine the ecological and social environments in which they operate (Muñoz \& Cohen, 2018). Thus, sustainable entrepreneurship begins with the identification of ecological or social problems, and then identifies possible solutions through innovation (Eller et al., 2020). Similarly, sustainability start-ups differ from conventional start-up companies in their pronounced value-based approach and intention to initiate social and environmental change in society (Bocken, 2015, p. 3).

The purpose of this research is to present a bibliometric analysis of the sustainable entrepreneurship, in order to have an approach to this topic and identify the main authors, countries and journals that investigate this topic. Similarly, by means of maps, visualize elements such as co-citation, bibliographic coupling and co-authoring. Likewise, the presentation of the citation structure by years, which allows us to understand the historical evolution of both the number of publications and citations.

This document is organised as follows. Section 1 reviews the bibliometric methods used herein. Section 2 presents the results including the citation structures of the most representa- 
tive publications, authors, institutions and countries for the topic of sustainable entrepreneurship. Also includes a graphic analysis of the bibliographic data using the VOSviewer software. Finally, the main discussions and conclusions.

\section{Bibliometric method}

In order to carry out the bibliometric analysis, the main collection of the Web of Science (WoS) database was consulted and the following search equation was used: Topic: ("sustainable entrepreneurship") or Topic: ("sustainability entrepreneurship") or Topic: ("sustainable venturing") or Topic: ("sustainable start-up") or Topic: ("sustainable innovation") or Topic: ("sustainab* entrepreneur*"). The search was refined excluding 2020 and only Article or Review document types were taken into account. The time frame was from 1968 to 2019 . The indices used were: SCI-EXPANDED, SSCI, A\&HCI, CPCI-S, CPCI-SSH, BKCI-S, BKCI-SSH, ESCI, CCR-EXPANDED, IC. In this sense, by refining the search with the above equation, 761 documents were found, of which 710 are Articles and 51 are Reviews. A bibliometric analysis is done based on these articles.

Broadus' research presents different definitions of the term bibliometric, a definition presented by the author is that of Porter who suggests that "bibliometrics is a set of methods used to study or measure texts and information of all forms of written communication, their authors and publication patterns" (Broadus, 1987, p. 374). In this sense, the bibliometric analysis allows quantitative analysis of the academic literature (Cancino et al., 2017; Merigó \& Yang, 2017; Pineda Ospina, 2015). The most representative publications, citations, authors, countries and journals are analysed, which allows us to get an idea of a certain field of research (Merigó et al., 2015).

There are several indicators to measure the academic production of authors, the most popular include the total number of papers published and total number of papers published in a given period of time. There are also indicators to measure the impact of publications, including the total number of citations, the average citations per paper and the impact of the journals where the papers are published, which should be taken into account in the bibliometric analysis (Alonso et al., 2009).

However, Hirsh in 2005 designed an indicator called index h, which takes into account the quantity and impact of the researcher's publications (Alonso et al., 2009). This revolves around the idea that "a scientist has index $\mathrm{h}$ if $\mathrm{h}$ of his or her Np papers have at least $\mathrm{h}$ citations each and the other (Np-h) papers have $\leq$ h citations each" (Hirsch, 2005, p. 16569). That is, if the index $\mathrm{h}$ of an author is $\mathrm{X}$, thus that $\mathrm{X}$ of his or her publications have been cited more than $\mathrm{X}$ times.

The main analyses include, among other: bibliographic coupling, co-citation, co-occurrence of key words. Next, each one is detailed (Boyack \& Klavans, 2010; Merigó et al., 2018; Zupic \& Čater, 2015): Bibliographic Coupling (Figure 2): When two papers have a common reference, that is, if paper $\mathrm{A}$ is cited in papers $\mathrm{B}$ and $\mathrm{C}$, it means that they are coupled bibliographically speaking. The greater the number of common references, the greater the intensity of the relationship (Kessler, 1963), see Figure 1. Co-citation: When two papers are cited in a single paper it means that they are co-cited, in other words, when papers A and C are cited in 
paper $\mathrm{B}$, this indicator allows the degree of relationship of the papers according to the citing authors, that is, that the more citations the two papers have in the same paper, the greater their relationship (Small, 1973), see Figure 2. Co-authorship: It refers to documents that have more than one author, which allows to identify scientific collaboration (Merigó et al., 2018). Co-occurrence of keywords: It identify keywords more frequently and those that appear more frequently in the same documents (Merigó et al., 2018).

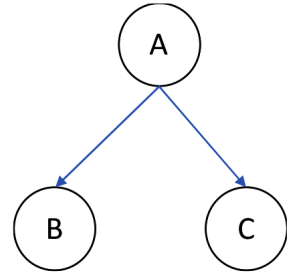

Figure 1. Example of bibliographic coupling example (Kessler, 1963)

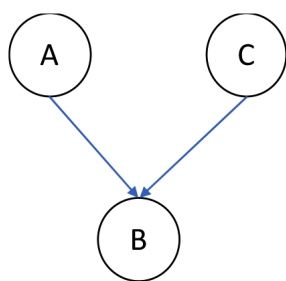

Figure 2. Example of co-citation (Small, 1973)

Finally, it is worth noting that the research that uses bibliometric analysis has focused on performing them when a journal is celebrating its anniversary (Biemans et al., 2007; Cancino et al., 2017; Merigó et al., 2018). They have also been performed focusing on a topic (Cancino et al., 2018; Fahimnia et al., 2015; Liao et al., 2018; Merigó et al., 2015; Merigó \& Yang, 2017; Zupic \& Čater, 2015) and in other cases they have focused on the publications of a country or region (Bonilla et al., 2015; Glänzel et al., 1999), among others.

\section{Results}

Since 2015, the amount of documents that have been published around the research topic of "Sustainable Entrepreneurship" has been increasing in a very representative way, having an upswing since 2011 as shown in the Figure 3. By the way (Wagner et al., 2019) mentions that as of 2009 is this increase. This originates since different disciplines have increased their interest to research the subject (Muñoz \& Cohen, 2018), together with the fact that the concept of sustainability is increasingly significant. In this sense, $78.6 \%$ of the documents published correspond to the time frame from 2015 to 2019. Figure 3 displays the evolution over time of the publications per year. It is worth noting that only papers and reviews are taken into account in the bibliometric analysis presented. In total, $93.3 \%$ correspond to papers and $6.7 \%$ to reviews.

To identify the main terms that were found in the systematic information search, the NVIVO (QSR International, 2020) software was used (version 12), the author, year, title, and summary were chosen as key data. Out of the 761 papers, the title and the summary were taken and the frequency of words analysis was carried out, which consists of identifying the most frequently used words, followed by a word cloud chart, which allows to identify the most frequently used words by the size of the text, the larger the text the greater the frequency. The main words are sustainable, innovation, environmental, business, entrepreneurship, among others, see Figure 4. 




Figure 3. Annual Number of Documents published in research on Sustainable Entrepreneurship

Regarding the terms of sustainability, entrepreneurship and innovation, the NVIVO Software was used to track the use of these throughout the years, using the abstract of the 761 papers as data. The following table shows the historical development of these three terms. It is found that there is a greater use of these terms in research since 2010. However, it is found that there is an increase in the use of terms in 2010 compared to previous years. It is also clear that the use of the term of sustainability is growing very programmatically, especially in the last four years. Figure 5 displays the increase in the use of words.

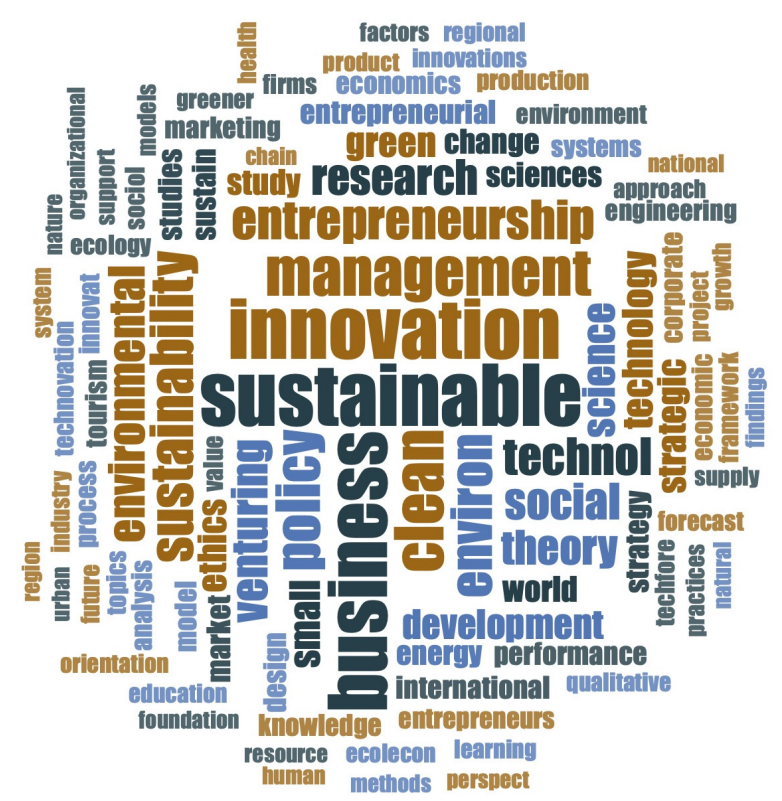

Figure 4. Word cloud source: own development using NVIVO 


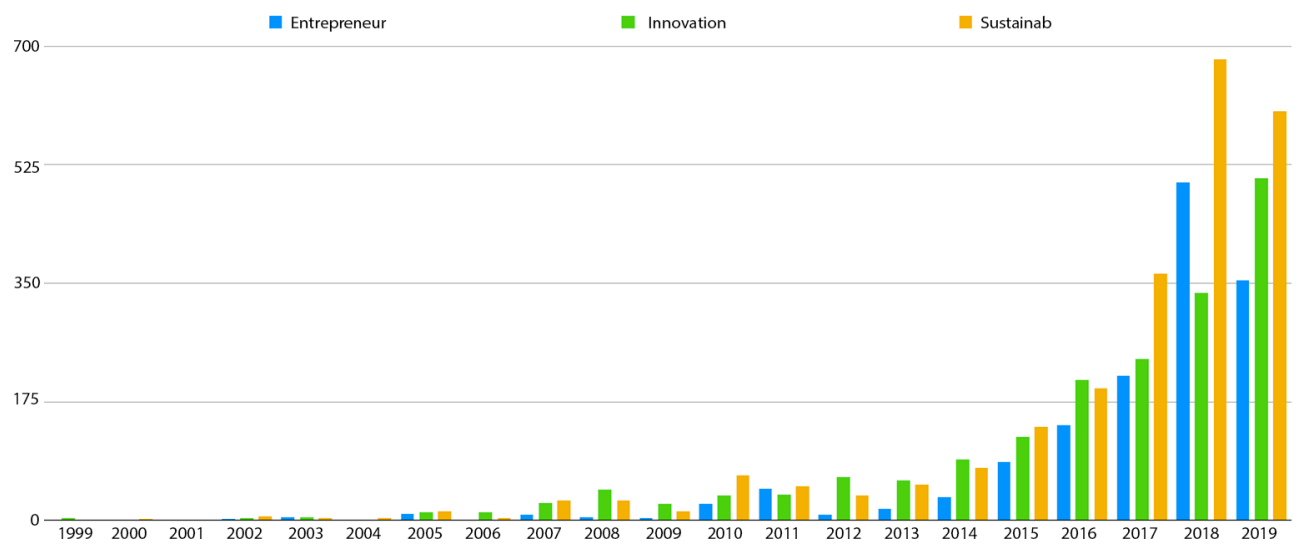

Figure 5. Development of the terms entrepreneur, innovation and sustainable

The general citation structure allows analysing the amount of documents in relation to a citation threshold (Cancino et al., 2017), in this sense, $28.52 \%$ of the documents have received at least 10 citations and $15.37 \%$ have received at least 20 citations. Only nine documents have received at least 300 citations and five documents have received at least 400 citations, see Table 1. Regarding index h, it stands at 50 for this group of documents, which means that 50 documents have received at least 50 citations.

In regards to the annual citation structure of the published documents, it is found that $74 \%$ have received at least one citation in documents indexed in the WoS database. $28.5 \%$ have received at least 10 citations, $3.2 \%$ at least 100 and $1.2 \%$ at least 300 citations, see Table 2 . The year with the most citations is 2010 with a total of 1,798 , with the main authors being (Bos-Brouwers, 2010; Hockerts \& Wüstenhagen, 2010; Short et al., 2010; Smith et al., 2010), followed by the year 2007 with 1,469, the main authors being (Cohen \& Winn, 2007; Dean \& McMullen, 2007; Hellström, 2007; Stirling, 2007).

Table 1. General citation structure (source: own elaboration based on WoS)

\begin{tabular}{|l|c|c|}
\hline \multicolumn{1}{|c|}{ Number of citations } & TP & $\%$ \\
\hline$\geq 400$ citation & 5 & $0.66 \%$ \\
\hline$\geq 300$ citation & 9 & $1.18 \%$ \\
\hline$\geq 200$ citation & 12 & $1.58 \%$ \\
\hline$\geq 100$ citation & 24 & $3.15 \%$ \\
\hline$\geq 50$ citation & 53 & $6.96 \%$ \\
\hline$\geq 20$ citation & 117 & $15.37 \%$ \\
\hline$\geq 10$ citation & 217 & $28.52 \%$ \\
\hline Total Papers & 761 & \\
\hline
\end{tabular}

Note: TP - Total Papers. 
Table 2. Annual citation structure on Sustainable Entrepreneurship research (source: own elaboration)

\begin{tabular}{|c|c|c|c|c|c|c|c|c|}
\hline Year & TP & TC & $\geq 1$ & $\geq 10$ & $\geq 50$ & $\geq 100$ & $\geq 200$ & $\geq 300$ \\
\hline 1999 & 1 & 5 & 1 & 0 & 0 & 0 & 0 & 0 \\
\hline 2000 & 1 & 1 & 1 & 0 & 0 & 0 & 0 & 0 \\
\hline 2001 & 1 & 0 & 0 & 0 & 0 & 0 & 0 & 0 \\
\hline 2002 & 2 & 133 & 2 & 2 & 2 & 0 & 0 & 0 \\
\hline 2003 & 2 & 141 & 2 & 2 & 2 & 0 & 0 & 0 \\
\hline 2004 & 1 & 10 & 1 & 1 & 0 & 0 & 0 & 0 \\
\hline 2005 & 6 & 210 & 6 & 4 & 2 & 0 & 0 & 0 \\
\hline 2006 & 2 & 17 & 2 & 0 & 0 & 0 & 0 & 0 \\
\hline 2007 & 9 & 1469 & 9 & 9 & 5 & 4 & 3 & 3 \\
\hline 2008 & 11 & 968 & 10 & 7 & 4 & 2 & 1 & 1 \\
\hline 2009 & 7 & 243 & 7 & 3 & 1 & 1 & 0 & 0 \\
\hline 2010 & 16 & 1798 & 15 & 12 & 7 & 6 & 3 & 2 \\
\hline 2011 & 30 & 1085 & 18 & 12 & 6 & 3 & 2 & 1 \\
\hline 2012 & 22 & 659 & 19 & 10 & 4 & 2 & 0 & 0 \\
\hline 2013 & 25 & 1271 & 23 & 14 & 4 & 2 & 2 & 2 \\
\hline 2014 & 27 & 983 & 20 & 15 & 5 & 3 & 1 & 0 \\
\hline 2015 & 50 & 749 & 45 & 23 & 4 & 0 & 0 & 0 \\
\hline 2016 & 86 & 974 & 79 & 31 & 2 & 1 & 0 & 0 \\
\hline 2017 & 108 & 1182 & 92 & 39 & 5 & 0 & 0 & 0 \\
\hline 2018 & 183 & 851 & 139 & 28 & 0 & 0 & 0 & 0 \\
\hline 2019 & 171 & 222 & 72 & 5 & 0 & 0 & 0 & 0 \\
\hline Total & 761 & 12971 & 563 & 217 & 53 & 24 & 12 & 9 \\
\hline$\%$ & $100 \%$ & & $74.0 \%$ & $28.5 \%$ & $7.0 \%$ & $3.2 \%$ & $1.6 \%$ & $1.2 \%$ \\
\hline
\end{tabular}

Note: TP and TC - Total Papers and citations; $\geq 300, \geq 250, \geq 200, \geq 150, \geq 100, \geq 50, \geq 10, \geq 5, \geq 1$ - Number of Papers with equal or more than $300,250,200,100,50,10,5$ and 1 citation.

As mentioned above, the research published in the WoS database related to Sustainable Entrepreneurship is increasing. In the search carried out, it was found that the first paper (taking into account the search equation mentioned in section 1) is from 1999; Table 3 displays the 20 most cited papers. Authors such as Schot, J; Geels, FW; Smith, A; Voss, JP; Grin, J; Boons, F; Ludeke-Freund, F; Dean, TJ; McMullen, JS; Cohen, B; Winn, MI; Schaltegger, S; Wagner, M. Similarly, 2010 is stands out with six papers in the top 20, for its part 2007 have four papers, the years 2011 and 2014, have three papers each in the top 20. It was also found that the paper with the most citations per year is that of Boons and Ludeke-Freund.

In relation to the authors, Table 4 contains the 15 authors with their respective institutions and country, who publish the most on Sustainable Entrepreneurship matters. Authors such as Bossink, Blok and Horisch stand out with 13, 10 and 7 publications respectively. Of the 20 authors that publish the most, there are ten that have more than 100 citations, and two of whom have more than 500 citations. In relation to the index h, one author have an index of six, eight authors have an index of four, six authors have an index of three and four authors have an index of two. 
Table 3. The 20 most cited documents between 1999 and 2019 (source: own elaboration)

\begin{tabular}{|c|c|c|c|c|c|}
\hline No. & $\mathrm{TC}$ & Title & Author/s & Year & $\mathrm{TC} / \mathrm{Y}$ \\
\hline 1 & 617 & $\begin{array}{l}\text { Strategic niche management and sustainable } \\
\text { innovation journeys: theory, findings, research } \\
\text { agenda, and policy }\end{array}$ & Schot \& Geels & 2008 & 56.1 \\
\hline 2 & 577 & $\begin{array}{l}\text { Innovation studies and sustainability transitions: } \\
\text { The allure of the multi-level perspective and its } \\
\text { challenges }\end{array}$ & Smith et al. & 2010 & 64.1 \\
\hline 3 & 550 & $\begin{array}{l}\text { Business models for sustainable innovation: state- } \\
\text { of-the-art and steps towards a research agenda }\end{array}$ & $\begin{array}{l}\text { Boons \& Lüdeke- } \\
\text { Freundthe Boons \& } \\
\text { Lüdeke-Freund }\end{array}$ & 2013 & 91.7 \\
\hline 4 & 420 & $\begin{array}{l}\text { Sustainable Entrepreneurship and Sustainability } \\
\text { Innovation: Categories and Interactions }\end{array}$ & $\begin{array}{l}\text { Schaltegger \& } \\
\text { Wagner }\end{array}$ & 2011 & 52.5 \\
\hline 5 & 406 & $\begin{array}{l}\text { Toward a theory of sustainable entrepreneurship: } \\
\text { Reducing environmental degradation through } \\
\text { entrepreneurial action }\end{array}$ & Dean \& McMullen & 2007 & 33.8 \\
\hline 6 & 386 & $\begin{array}{l}\text { Market imperfections, opportunity and } \\
\text { sustainable entrepreneurship }\end{array}$ & Cohen \& Winn & 2007 & 32.2 \\
\hline 7 & 359 & $\begin{array}{l}\text { A general framework for analysing diversity in } \\
\text { science, technology and society }\end{array}$ & Stirling & 2007 & 29.9 \\
\hline 8 & 314 & $\begin{array}{l}\text { Greening Goliaths versus emerging Davids - } \\
\text { Theorizing about the role of incumbents and new } \\
\text { entrants in sustainable entrepreneurship }\end{array}$ & $\begin{array}{l}\text { Hockerts \& } \\
\text { Wüstenhagen }\end{array}$ & 2010 & 34.9 \\
\hline 9 & 300 & $\begin{array}{l}\text { Sustainable innovation, business models and } \\
\text { economic performance: an overview }\end{array}$ & $\begin{array}{l}\text { Frank Boons, Carlos } \\
\text { Montalvo, Jaco } \\
\text { Quist, \& Marcus } \\
\text { Wagner }\end{array}$ & 2013 & 50.0 \\
\hline 10 & 286 & $\begin{array}{l}\text { Sustainability-oriented innovation of SMEs: a } \\
\text { systematic review }\end{array}$ & Klewitz \& Hansen & 2014 & 57.2 \\
\hline 11 & 224 & $\begin{array}{l}\text { Corporate Sustainability and Innovation in SMEs: } \\
\text { Evidence of Themes and Activities in Practice }\end{array}$ & Bos-Brouwers, HEJ & 2010 & 24.9 \\
\hline 12 & 207 & $\begin{array}{l}\text { The New Field of Sustainable Entrepreneurship: } \\
\text { Studying Entrepreneurial Action Linking } \\
\text { "What Is to Be Sustained" with "What Is to Be } \\
\text { Developed" }\end{array}$ & Shepherd \& Patzelt & 2011 & 25.9 \\
\hline 13 & 183 & $\begin{array}{l}\text { Green innovation in technology and innovation } \\
\text { management - an exploratory literature review }\end{array}$ & $\begin{array}{l}\text { Schiederig, Tietze, } \\
\text { \& Herstatt }\end{array}$ & 2012 & 26.1 \\
\hline 14 & 180 & $\begin{array}{l}\text { The influence of sustainability orientation on } \\
\text { entrepreneurial intentions - Investigating the role } \\
\text { of business experience }\end{array}$ & Kuckertz \& Wagner & 2010 & 20.0 \\
\hline 15 & 179 & $\begin{array}{l}\text { The entrepreneur-environment nexus: } \\
\text { Uncertainty, innovation, and allocation }\end{array}$ & \begin{tabular}{|l} 
York \& \\
Venkataraman
\end{tabular} & 2010 & 19.9 \\
\hline 16 & 173 & $\begin{array}{l}\text { Evolutionary approaches for sustainable } \\
\text { innovation policies: From niche to paradigm? }\end{array}$ & Nill \& Kemp & 2009 & 17.3 \\
\hline 17 & 163 & Transforming Innovation for Sustainability & Leach et al. & 2012 & 23.3 \\
\hline 18 & 162 & $\begin{array}{l}\text { Overcoming barriers to innovation and diffusion } \\
\text { of cleaner technologies: some features of a } \\
\text { sustainable innovation policy regime }\end{array}$ & Foxon \& Pearson & 2008 & 14.7 \\
\hline
\end{tabular}


End of Table 3

\begin{tabular}{|c|c|l|l|c|c|}
\hline No. & TC & \multicolumn{1}{|c|}{ Title } & \multicolumn{1}{|c|}{ Author/s } & Year & TC/Y \\
\hline 19 & 141 & $\begin{array}{l}\text { Escaping the green prison: Entrepreneurship } \\
\text { and the creation of opportunities for sustainable } \\
\text { development }\end{array}$ & $\begin{array}{l}\text { Pacheco, Dean, \& } \\
\text { Payne }\end{array}$ & 2010 & 15.7 \\
\hline 20 & 140 & $\begin{array}{l}\text { Adopting Sustainable Innovation: What Makes } \\
\text { Consumers Sign up to Green Electricity? }\end{array}$ & Ozaki & 2011 & 17.5 \\
\hline
\end{tabular}

Note: TC - Total number of citations. TC/Y - It is the total of citations on the number of years that the document has been published.

On the other hand, regarding the documents most cited in the research on Sustainable Entrepreneurship, we find that the most representative authors are: Dean $\mathrm{Tj}$, Schaltegger S, Cohen B, Hockerts K, and Hall Jk., the main journals are also identified, namely: Journal of Business Venturing, Journal of Cleaner Production, Academic of Management Review and Entrepreneurship Theory and Practice, see Table 5.

Table 4. The 15 authors that publish the most on the topic of Sustainable Entrepreneurship (source: own elaboration)

\begin{tabular}{|c|l|c|l|c|c|c|c|c|c|c|c|}
\hline No. & Author & TP & \multicolumn{1}{|c|}{ University } & Country & TC & H & TC/TP & $\geq 100$ & $\geq 50$ & $\geq 10$ & $\geq 1$ \\
\hline 1 & $\begin{array}{l}\text { Bossink } \\
\text { Bart }\end{array}$ & 13 & $\begin{array}{l}\text { Vrije Univ } \\
\text { Amsterdam } \\
\text { Univ Twente }\end{array}$ & Netherlands & 8 & 2 & 0.62 & 0 & 0 & 0 & 4 \\
\hline 2 & $\begin{array}{l}\text { Blok } \\
\text { Vicent }\end{array}$ & 10 & $\begin{array}{l}\text { Wageningen } \\
\text { University \& } \\
\text { Research }\end{array}$ & Netherlands & 235 & 6 & 23.50 & 0 & 2 & 4 & 10 \\
\hline 3 & $\begin{array}{l}\text { Horisch } \\
\text { Jacob }\end{array}$ & 7 & Alanus Univ & Germany & 109 & 4 & 15.57 & 0 & 0 & 4 & 7 \\
\hline 4 & $\begin{array}{l}\text { Tsai } \\
\text { Snag- } \\
\text { Bing }\end{array}$ & 6 & $\begin{array}{l}\text { Dalian Univ } \\
\text { Technol } \\
\text { Univ Elect } \\
\text { Sci \& } \\
\text { Technol }\end{array}$ & China & 36 & 2 & 6.00 & 0 & 0 & 1 & 5 \\
\hline 5 & $\begin{array}{l}\text { Quist } \\
\text { Jaco }\end{array}$ & 5 & $\begin{array}{l}\text { Delft Univ } \\
\text { Technol }\end{array}$ & Netherlands & 382 & 4 & 76.4 & 1 & 1 & 4 & 5 \\
\hline 6 & $\begin{array}{l}\text { Ratten } \\
\text { Vanessa }\end{array}$ & 5 & $\begin{array}{l}\text { La Trobe } \\
\text { Univ }\end{array}$ & Australia & 0 & 0 & 0 & 0 & 0 & 0 & 0 \\
\hline 7 & $\begin{array}{l}\text { Schalte- } \\
\text { gger } \\
\text { Stefan }\end{array}$ & 5 & $\begin{array}{l}\text { Leuphana } \\
\text { Univ } \\
\text { Lueneburg }\end{array}$ & Germany & 522 & 4 & 104.4 & 1 & 2 & 2 & 4 \\
\hline 8 & $\begin{array}{l}\text { Tvarona- } \\
\text { viciene } \\
\text { Manuela }\end{array}$ & 5 & $\begin{array}{l}\text { Vilnius } \\
\text { Gediminas } \\
\text { Tech Univ }\end{array}$ & Lithuania & 53 & 4 & 10.6 & 0 & 0 & 4 & 5 \\
\hline 9 & $\begin{array}{l}\text { Wagner } \\
\text { Marcus }\end{array}$ & 5 & $\begin{array}{l}\text { Univ } \\
\text { Wurzburg }\end{array}$ & Germany & 900 & 3 & 180 & 3 & 3 & 3 & 3 \\
\hline 10 & $\begin{array}{l}\text { York } \\
\text { Jeffrey G }\end{array}$ & 5 & $\begin{array}{l}\text { Univ } \\
\text { Virginia }\end{array}$ & USA & 274 & 3 & 54.8 & 1 & 1 & 3 & 4 \\
\hline
\end{tabular}


End of Table 4

\begin{tabular}{|c|c|c|c|c|c|c|c|c|c|c|c|}
\hline No. & Author & $\mathrm{TP}$ & University & Country & TC & $\mathrm{H}$ & TC/TP & $\geq 100$ & $\geq 50$ & $\geq 10$ & $\geq 1$ \\
\hline 11 & $\begin{array}{l}\text { Chare- } \\
\text { onpanich } \\
\text { Metta }\end{array}$ & 4 & $\begin{array}{l}\text { Kasetsart } \\
\text { Univ }\end{array}$ & \begin{tabular}{|l|} 
Thailand \\
\end{tabular} & 36 & 3 & 9 & 0 & 0 & 2 & 4 \\
\hline 12 & $\begin{array}{l}\text { Cohen } \\
\text { Boyd }\end{array}$ & 4 & $\begin{array}{l}\text { Univ Victoria } \\
\text { EADA } \\
\text { Business } \\
\text { Univ Vic } \\
\text { Univ } \\
\text { Desarrollo }\end{array}$ & $\begin{array}{l}\text { Canada } \\
\text { Spain } \\
\text { Australia } \\
\text { Chile }\end{array}$ & 412 & 4 & 103 & 1 & 1 & 2 & 4 \\
\hline 13 & \begin{tabular}{|l|} 
Dickel \\
Petra
\end{tabular} & 4 & Univ Kiel & Germany & 14 & 2 & 3.5 & 0 & 0 & 1 & 3 \\
\hline 14 & $\begin{array}{l}\text { Donphai } \\
\text { Walee- } \\
\text { porn }\end{array}$ & 4 & $\begin{array}{l}\text { Kasetsart } \\
\text { Univ }\end{array}$ & Thailand & 36 & 3 & 9 & 0 & 0 & 2 & 4 \\
\hline 15 & $\begin{array}{l}\text { Fichter } \\
\text { Klaus }\end{array}$ & 4 & $\begin{array}{l}\text { Carl von } \\
\text { Ossietzky } \\
\text { Univ } \\
\text { Oldenburg } \\
\text { Borderstep } \\
\text { Inst Innovat } \\
\text { \& Sustainabil }\end{array}$ & Germany & 29 & 3 & 7.25 & 0 & 0 & 2 & 3 \\
\hline
\end{tabular}

Note: Abbreviations are shown in Table 2.

Table 5. Most cited papers in research on sustainable entrepreneurship (source: own elaboration)

\begin{tabular}{|c|l|c|c|}
\hline No. & \multicolumn{1}{|c|}{ Reference (first author only) } & TC & TLS \\
\hline 1 & Dean Tj, 2007, J Business Venturing, V22, P50 & 152 & 1757 \\
\hline 2 & Schaltegger S, 2011, Bus Strateg Environ, V20, P222 & 143 & 1622 \\
\hline 3 & Cohen B, 2007, J Business Venturing, V22, P29 & 131 & 1534 \\
\hline 4 & Hockerts K, 2010, J Business Venturing, V25, P481 & 99 & 1357 \\
\hline 5 & Hall Jk, 2010, J Business Venturing, V25, P439 & 104 & 1285 \\
\hline 6 & Shepherd Da, 2011, Entrep Theory Pract, V35, P137 & 100 & 1103 \\
\hline 7 & Pacheco Df, 2010, J Business Venturing, V25, P464 & 67 & 973 \\
\hline 8 & Kuckertz A, 2010, J Business Venturing, v25, p524 & 65 & 906 \\
\hline 9 & York Jg, 2010, J Business Venturing, V25, P449 & 64 & 906 \\
\hline 10 & Parrish Bd, 2010, J Business Venturing, V25, P510 & 62 & 828 \\
\hline
\end{tabular}

Note: TC - Total Citations. TLS - Total Link Strength.

However, analysing the countries with the most publications, it has been found that the Netherlands is the country with the most papers published on the topic of Sustainable Entrepreneurship, followed by the USA, Germany and England. These countries reached at least 300 citations in one or more papers, as did Canada, Denmark and Switzerland, see Table 6. During the first ten years (1999 to 2008) the USA published more papers than Netherlands, followed by England. In the eleven years that followed (2009 to 2019), the Netherlands leads 
the field in terms of publications. Likewise, the USA stands out for having more publications in the 2008, 2009 and 2012, while the Netherlands stood out from 2013 to 2015 and Germany in 2017 and in 2018, see Table 7.

Table 6. The 11 Countries that publish the most on the topic of Sustainable Entrepreneurship (source: own elaboration)

\begin{tabular}{|c|l|c|c|c|c|c|c|c|c|c|c|c|}
\hline No. & \multicolumn{1}{|c|}{ Country } & TP & TC & $\mathrm{H}$ & $\begin{array}{c}\text { TC } / \\
\mathrm{TP}\end{array}$ & $\begin{array}{c}\% / \\
761\end{array}$ & $\geq 300$ & $\geq 200$ & $\geq 100$ & $\geq 50$ & $\geq 10$ & $\geq 1$ \\
\hline 1 & Netherlands & 102 & 3789 & 25 & 37.15 & $13 \%$ & 4 & 5 & 6 & 14 & 46 & 80 \\
\hline 2 & USA & 97 & 2366 & 24 & 24.39 & $13 \%$ & 1 & 2 & 5 & 13 & 42 & 74 \\
\hline 3 & Germany & 84 & 3462 & 18 & 41.21 & $11 \%$ & 4 & 6 & 8 & 12 & 29 & 67 \\
\hline 4 & England & 80 & 2676 & 24 & 33.45 & $11 \%$ & 2 & 2 & 5 & 12 & 39 & 72 \\
\hline 5 & Spain & 58 & 624 & 12 & 10.76 & $8 \%$ & 0 & 0 & 1 & 2 & 16 & 45 \\
\hline 6 & Italy & 55 & 361 & 11 & 6.56 & $7 \%$ & 0 & 0 & 0 & 0 & 14 & 42 \\
\hline 7 & Peoples R China & 49 & 313 & 9 & 6.39 & $6 \%$ & 0 & 0 & 1 & 1 & 9 & 27 \\
\hline 8 & Brazil & 42 & 367 & 8 & 8.74 & $6 \%$ & 0 & 0 & 1 & 3 & 8 & 23 \\
\hline 9 & Denmark & 34 & 666 & 11 & 19.59 & $4 \%$ & 1 & 1 & 1 & 3 & 11 & 30 \\
\hline 10 & Canada & 31 & 640 & 10 & 20.65 & $4 \%$ & 1 & 1 & 1 & 2 & 10 & 29 \\
\hline 11 & Sweden & 31 & 446 & 10 & 14.39 & $4 \%$ & 0 & 0 & 1 & 2 & 11 & 24 \\
\hline
\end{tabular}

Note: Abbreviations are shown in Table 2.

Table 7. Evolution over time of publications by country (source: own elaboration)

\begin{tabular}{|l|c|c|c|c|c|c|c|c|c|c|c|c|c|c|c|c|c|c|c|c|c|}
\hline $\begin{array}{c}\text { Coun- } \\
\text { try }\end{array}$ & 99 & 00 & 01 & 02 & 03 & 04 & 05 & 06 & 07 & 08 & 09 & 10 & 11 & 12 & 13 & 14 & 15 & 16 & 17 & 18 & 19 \\
\hline $\begin{array}{l}\text { Nether- } \\
\text { lands }\end{array}$ & 0 & 0 & 0 & 1 & 0 & 0 & 1 & 1 & 1 & 3 & 1 & 6 & 11 & 3 & 9 & 7 & 9 & 10 & 9 & 17 & 13 \\
\hline USA & 0 & 1 & 0 & 0 & 2 & 1 & 0 & 0 & 1 & 4 & 3 & 4 & 10 & 4 & 6 & 4 & 7 & 9 & 9 & 13 & 19 \\
\hline $\begin{array}{l}\text { Germa- } \\
\text { ny }\end{array}$ & 1 & 0 & 0 & 0 & 0 & 0 & 2 & 0 & 1 & 0 & 0 & 2 & 3 & 2 & 3 & 3 & 5 & 7 & 16 & 24 & 15 \\
\hline $\begin{array}{l}\text { Eng- } \\
\text { land }\end{array}$ & 0 & 0 & 0 & 0 & 0 & 0 & 0 & 1 & 4 & 1 & 1 & 2 & 4 & 3 & 2 & 5 & 7 & 11 & 6 & 12 & 8 \\
\hline Spain & 0 & 0 & 0 & 0 & 0 & 0 & 0 & 0 & 2 & 0 & 1 & 1 & 2 & 1 & 0 & 0 & 2 & 5 & 9 & 20 & 15 \\
\hline Italy & 0 & 0 & 0 & 0 & 0 & 0 & 0 & 0 & 0 & 0 & 0 & 0 & 1 & 2 & 0 & 0 & 0 & 7 & 10 & 16 & 19 \\
\hline $\begin{array}{l}\text { Peoples } \\
\text { R } \\
\text { China }\end{array}$ & 0 & 0 & 0 & 0 & 0 & 0 & 0 & 0 & 0 & 0 & 0 & 0 & 1 & 0 & 1 & 1 & 2 & 2 & 5 & 14 & 23 \\
\hline Brazil & 0 & 0 & 0 & 0 & 0 & 0 & 0 & 0 & 0 & 0 & 0 & 0 & 0 & 0 & 0 & 0 & 3 & 5 & 12 & 13 & 9 \\
\hline $\begin{array}{l}\text { Den- } \\
\text { mark }\end{array}$ & 0 & 0 & 0 & 0 & 0 & 0 & 0 & 0 & 1 & 0 & 0 & 2 & 0 & 0 & 0 & 1 & 5 & 4 & 9 & 9 & 3 \\
\hline Canada & 0 & 0 & 0 & 0 & 0 & 0 & 0 & 0 & 0 & 1 & 1 & 1 & 1 & 2 & 0 & 1 & 1 & 4 & 6 & 5 & 8 \\
\hline Sweden & 0 & 0 & 0 & 0 & 0 & 0 & 1 & 0 & 0 & 1 & 0 & 1 & 0 & 2 & 0 & 0 & 0 & 5 & 3 & 10 & 8 \\
\hline
\end{tabular}

Note: TP - Total Papers; 99, 00, 01, 02, 03, 04, 05, 06, 07, 08, 09, 10, 11, 12, 1, 14, 15, 16, 17, 18, 19 year of publication. 
On the other hand, the leading journals to publish papers related to the topic of sustainable entrepreneurship according to the search carried out in WoS are the following: Journal of Cleaner Production and Sustainability, the first has an impact factor of 6.395 as of 2018 and the second of 2.592 , see Table 8 . In relation to the citation structure, only three journals have had at least 300 citations or more in a document, the citation structure is found in Table 8. When analysing the evolution over time of journal publications, it is clear, as mentioned before, that as of 2015 there is a representative growth in publications on the subject of sustainable entrepreneurship. However, there is a significant amount of publications in 2011, see Table 9.

Table 8. Citation structure of the journals that publish the most (source: Own elaboration)

\begin{tabular}{|c|c|c|c|c|c|c|c|c|c|c|c|c|c|}
\hline Journal & $\mathrm{TP}$ & $\mathrm{TC}$ & $\mathrm{H}$ & $\begin{array}{c}\mathrm{TC} / \\
\mathrm{TP}\end{array}$ & $\begin{array}{c}\text { IF } \\
2018\end{array}$ & $\begin{array}{c}\text { IF } 5 \\
\text { years }\end{array}$ & $\%$ & $\geq 300$ & $\geq 200$ & $\geq 100$ & $\geq 50$ & $\geq 10$ & $\geq 1$ \\
\hline $\begin{array}{l}\text { Journal of } \\
\text { Cleaner } \\
\text { Production }\end{array}$ & 101 & 3028 & 25 & 29,98 & 6.395 & 7.051 & $13 \%$ & 2 & 3 & 5 & 12 & 58 & 94 \\
\hline Sustainability & 99 & 431 & 11 & 4.35 & 2.592 & 2.801 & $13 \%$ & 0 & 0 & 0 & 0 & 15 & 67 \\
\hline $\begin{array}{l}\text { Entrepre- } \\
\text { neurship and } \\
\text { Sustainability } \\
\text { Issues }\end{array}$ & 18 & 115 & 7 & 6.39 & NA & NA & $2 \%$ & 0 & 0 & 0 & 0 & 5 & 17 \\
\hline $\begin{array}{l}\text { Business } \\
\text { Strategy and } \\
\text { the Environ- } \\
\text { ment }\end{array}$ & 16 & 1069 & 12 & 66.81 & 6.381 & 7.557 & $2 \%$ & 1 & 2 & 3 & 5 & 12 & 14 \\
\hline $\begin{array}{l}\text { Corporate } \\
\text { Social } \\
\text { Responsibility } \\
\text { and Environ- } \\
\text { mental } \\
\text { Management }\end{array}$ & 14 & 87 & 3 & 6.21 & 5.513 & 7.131 & $2 \%$ & 0 & 0 & 0 & 1 & 1 & 8 \\
\hline $\begin{array}{l}\text { International } \\
\text { Journal of } \\
\text { Entrepre- } \\
\text { neurial } \\
\text { Venturing }\end{array}$ & 11 & 46 & 4 & 4.18 & NA & NA & $1 \%$ & 0 & 0 & 0 & 0 & 1 & 10 \\
\hline $\begin{array}{l}\text { CSR Sustain- } \\
\text { ability } \\
\text { Ethics and } \\
\text { Governance }\end{array}$ & 10 & 6 & 1 & 0.60 & NA & NA & $1 \%$ & 0 & 0 & 0 & 0 & 0 & 3 \\
\hline $\begin{array}{l}\text { Managing } \\
\text { Environ- } \\
\text { mentally } \\
\text { Sustainable } \\
\text { Innovation } \\
\text { Insights from } \\
\text { the Const- } \\
\text { ruction } \\
\text { Industry }\end{array}$ & 10 & 1 & 1 & 0.10 & NA & NA & $1 \%$ & 0 & 0 & 0 & 0 & 0 & 1 \\
\hline
\end{tabular}


End of Table 8

\begin{tabular}{|l|c|c|c|c|c|c|c|c|c|c|c|c|c|}
\hline Journal & TP & TC & H & $\begin{array}{c}\text { TC / } \\
\text { TP }\end{array}$ & $\begin{array}{c}\text { IF } \\
2018\end{array}$ & $\begin{array}{c}\text { IF 5 } \\
\text { years }\end{array}$ & $\%$ & $\geq 300$ & $\geq 200$ & $\geq 100$ & $\geq 50$ & $\geq 10$ & $\geq 1$ \\
\hline $\begin{array}{l}\text { Routledge } \\
\text { Studies in } \\
\text { Innovation } \\
\begin{array}{l}\text { Organization } \\
\text { and Techno- } \\
\text { logy }\end{array}\end{array}$ & 10 & 1 & 1 & 0.10 & NA & NA & $1 \%$ & 0 & 0 & 0 & 0 & 0 & 1 \\
\hline $\begin{array}{l}\text { Small } \\
\text { Business } \\
\text { Economics }\end{array}$ & 10 & 103 & 6 & 10.30 & 3.56 & 4.45 & $1 \%$ & 0 & 0 & 0 & 0 & 4 & 6 \\
\hline
\end{tabular}

Note: Abbreviations are shown in Table 2. NA: Not Available.

Table 9. Evolution over time of publications by journal (source: Own elaboration)

\begin{tabular}{|c|c|c|c|c|c|c|c|c|c|c|c|c|c|c|c|c|c|c|c|c|c|}
\hline Journal & 99 & 00 & 01 & 02 & 03 & 04 & 05 & 06 & 07 & 08 & 09 & 10 & 11 & 12 & 13 & 14 & 15 & 16 & 17 & 18 & 19 \\
\hline $\begin{array}{l}\text { Journal of } \\
\text { Cleaner } \\
\text { Pro- } \\
\text { duction }\end{array}$ & 0 & 0 & 1 & 0 & 0 & 0 & 2 & 0 & 2 & 1 & 0 & 2 & 0 & 0 & 6 & 4 & 6 & 14 & 19 & 28 & 16 \\
\hline $\begin{array}{l}\text { Sustain- } \\
\text { ability }\end{array}$ & 0 & 0 & 0 & 0 & 0 & 0 & 0 & 0 & 0 & 0 & 0 & 0 & 0 & 0 & 0 & 1 & 2 & 9 & 11 & 30 & 46 \\
\hline $\begin{array}{l}\text { Entrepre- } \\
\text { neurship } \\
\text { and } \\
\text { Sustain- } \\
\text { ability } \\
\text { Issues }\end{array}$ & 0 & 0 & 0 & 0 & 0 & 0 & 0 & 0 & 0 & 0 & 0 & 0 & 0 & 0 & 0 & 0 & 6 & 4 & 2 & 4 & 2 \\
\hline \begin{tabular}{|l|} 
Business \\
Strategy \\
and the \\
Environ- \\
ment \\
\end{tabular} & 0 & 0 & 0 & 0 & 0 & 0 & 0 & 0 & 0 & 0 & 0 & 1 & 2 & 1 & 0 & 1 & 2 & 1 & 3 & 2 & 3 \\
\hline \begin{tabular}{|l|} 
Corporate \\
Social \\
Respon- \\
sibility \\
and \\
Environ- \\
mental \\
Mana- \\
gement \\
\end{tabular} & 0 & 0 & 0 & 0 & 0 & 0 & 0 & 0 & 0 & 0 & 0 & 1 & 0 & 1 & 0 & 0 & 0 & 0 & 0 & 0 & 12 \\
\hline \begin{tabular}{|l|} 
Inter- \\
national \\
Journal of \\
Entrepre- \\
neurial \\
Venturing \\
\end{tabular} & 0 & 0 & 0 & 0 & 0 & 0 & 0 & 0 & 0 & 0 & 0 & 0 & 0 & 0 & 0 & 0 & 1 & 0 & 1 & 7 & 1 \\
\hline
\end{tabular}


End of Table 9

\begin{tabular}{|c|c|c|c|c|c|c|c|c|c|c|c|c|c|c|c|c|c|c|c|c|c|}
\hline Journal & 99 & 00 & 01 & 02 & 03 & 04 & 05 & 06 & 07 & 08 & 09 & 10 & 11 & 12 & 13 & 14 & 15 & 16 & 17 & 18 & 19 \\
\hline $\begin{array}{l}\text { CSR } \\
\text { Sustain- } \\
\text { ability } \\
\text { Ethics } \\
\text { and } \\
\text { Gover- } \\
\text { nance } \\
\end{array}$ & 0 & 0 & 0 & 0 & 0 & 0 & 0 & 0 & 0 & 0 & 0 & 0 & 0 & 0 & 0 & 0 & 1 & 0 & 1 & 7 & 1 \\
\hline $\begin{array}{l}\text { Managing } \\
\text { Environ- } \\
\text { mentally } \\
\text { Sustain- } \\
\text { able } \\
\text { Inno- } \\
\text { vation } \\
\text { Insights } \\
\text { from the } \\
\text { Const- } \\
\text { ruction } \\
\text { Industry }\end{array}$ & 0 & 0 & 0 & 0 & 0 & 0 & 0 & 0 & 0 & 0 & 0 & 0 & 10 & 0 & 0 & 0 & 0 & 0 & 0 & 0 & 0 \\
\hline \begin{tabular}{|l} 
Routledge \\
Studies \\
in Inno- \\
vation \\
Organi- \\
zation \\
and \\
Techno- \\
logy
\end{tabular} & 0 & 0 & 0 & 0 & 0 & 0 & 0 & 0 & 0 & 0 & 0 & 0 & 10 & 0 & 0 & 0 & 0 & 0 & 0 & 0 & 0 \\
\hline \begin{tabular}{|l|} 
Small \\
Business \\
Econo- \\
mics
\end{tabular} & 0 & 0 & 0 & 0 & 0 & 0 & 0 & 0 & 0 & 0 & 0 & 0 & 0 & 0 & 1 & 0 & 1 & 0 & 1 & 1 & 6 \\
\hline
\end{tabular}

Note: Abbreviations are shown in Table 7.

The subject of sustainable entrepreneurship is addressed, according to the categories defined by the WoS database, from the standpoint of the Green Sustainable Science Technology, environmental sciences, management, business, and environmental studies, among others, see Table 10. Management and business are the main categories that have had at least 300 citations or more in a document. Similarly, in relation to the research areas, it has been found that this is the case for business economics, environmental and ecological sciences, technology sciences and engineering, among others, see Table 11.

Table 10. Main categories in WoS and citation structure (source: own elaboration)

\begin{tabular}{|c|c|c|c|c|c|c|c|c|c|c|c|}
\hline WoS Categories & TP & $\%$ & TC & H & C/P & $\geq 300$ & $\geq 250$ & $\geq 200$ & $\geq 100$ & $\geq 10$ & $\geq 1$ \\
\hline $\begin{array}{l}\text { Green Sustainable } \\
\text { Science Technology }\end{array}$ & 245 & $32 \%$ & 3912 & 28 & 16 & 2 & 3 & 6 & 15 & 84 & 190 \\
\hline
\end{tabular}


End of Table 10

\begin{tabular}{|l|c|c|c|c|c|c|c|c|c|c|c|}
\hline \multicolumn{1}{|c|}{ WoS Categories } & $\mathrm{TP}$ & $\%$ & $\mathrm{TC}$ & $\mathrm{H}$ & $\mathrm{C} / \mathrm{P}$ & $\geq 300$ & $\geq 250$ & $\geq 200$ & $\geq 100$ & $\geq 10$ & $\geq 1$ \\
\hline $\begin{array}{l}\text { Environmental } \\
\text { Sciences }\end{array}$ & 236 & $31 \%$ & 3917 & 28 & 17 & 2 & 3 & 6 & 14 & 86 & 186 \\
\hline Management & 218 & $29 \%$ & 4332 & 26 & 20 & 3 & 4 & 7 & 18 & 60 & 159 \\
\hline Business & 214 & $28 \%$ & 4823 & 30 & 23 & 4 & 6 & 11 & 24 & 64 & 159 \\
\hline $\begin{array}{l}\text { Environmental } \\
\text { Studies }\end{array}$ & 175 & $23 \%$ & 2467 & 22 & 14 & 1 & 1 & 5 & 11 & 44 & 125 \\
\hline
\end{tabular}

Note: Abbreviations are shown in Table 2.

Table 11. Main research and citation structure areas (source: own elaboration)

\begin{tabular}{|l|c|c|c|c|c|c|c|c|c|c|c|}
\hline \multicolumn{1}{|c|}{ Research areas } & $\mathrm{TP}$ & $\%$ & $\mathrm{TC}$ & $\mathrm{H}$ & $\mathrm{TC} / \mathrm{TP}$ & $\geq 300$ & $\geq 200$ & $\geq 100$ & $\geq 50$ & $\geq 10$ & $\geq 1$ \\
\hline Business Economics & 353 & $46 \%$ & 7128 & 36 & 20.19 & 6 & 8 & 14 & 30 & 94 & 257 \\
\hline $\begin{array}{l}\text { Environmental } \\
\text { Sciences Ecology }\end{array}$ & 298 & $39 \%$ & 5658 & 33 & 18.99 & 3 & 5 & 10 & 24 & 109 & 232 \\
\hline $\begin{array}{l}\text { Science Technology } \\
\text { Other Topics }\end{array}$ & 257 & $34 \%$ & 5007 & 29 & 19.48 & 4 & 5 & 8 & 17 & 91 & 201 \\
\hline Engineering & 147 & $19 \%$ & 3700 & 28 & 25.17 & 2 & 3 & 5 & 16 & 76 & 129 \\
\hline $\begin{array}{l}\text { Social Sciences Other } \\
\text { Topics }\end{array}$ & 37 & $5 \%$ & 327 & 9 & 8.84 & 0 & 0 & 0 & 3 & 8 & 26 \\
\hline
\end{tabular}

Note: Abbreviations are shown in Table 2.

\section{Graphic Analysis with VOSviewer}

This section aims to present a more detailed analysis to the citation structure. The software used for this analysis was VOSviewer, (van Eck \& Waltman, 2020) (version 1.6.14), this software allows to create and visualise, taking into account the map co-citation of author or journal (Liao et al., 2018; van Eck \& Waltman, 2010), bibliometric networks based on citation, co-citation, co-authorship, bibliographic coupling, among others (Merigó et al., 2018). With regard to the co-citation of journals, between 1999 and 2019, it is found that the most representative journals are: Journal of Cleaner Production, Journal of Business Venturing, Entrepreneurship Theory and Practice, Academy of Management Review, Research Policy and Strategic Management Journal. The more papers published the larger the size of the node, in the same way the distance between two nodes means that the frequency of citations between these, the greater the distance, the lower the frequency of citations and vice versa (Liao et al., 2018). Figure 6 shows that the Journal of Cleaner Production is the most cited and has the broadest network just like the Journal of Business Venturing. It is worth noting that the colours of Figure 6 represent the group to which each journal belongs. The threshold used was 20 documents and the 100 most representative connections. In this figure, six clusters are identified, the red and green clusters are the ones that have the most connections with the greatest number of co-citations.

The bibliographic coupling shows the papers that refer to the same set of cited papers (Boyack \& Klavans, 2010). Figure 7 shows how the authors are bibliographically coupled. The 




Figure 6. Co-citation of journals

minimum threshold of 4 documents was used and the 100 most representative connections. Figure 7 is consistent with the results shown in Table 5, with Bossink, Blok, York, Cohen, Muñoz and Tsai being the most representative. This figure also shows the networks that are created between the authors, five clusters are identified, the main one is the red one, which contains a higher concentration of connections. In this cluster we find that York, Schaltegger have a stronger connection and therefore appear closer, which implies that it is common for researchers to quote these two authors in the same document.

Figure 8 contains the bibliographic coupling between countries, the main countries that create documents related to the topic of sustainable entrepreneurship are the Netherlands, the USA, England and Germany, in accordance with what is presented in Table 6. This map also shows the relationships that exist between countries, with Spain, the USA and the Netherlands close to each other, which means they have greater connections. This figure was made with a threshold of at least five documents and 100 connections.

Figure 9 contains the co-authorship by country, showing the most influential countries and the degree of communication between them. While it is similar to Figure 8 on biblio-

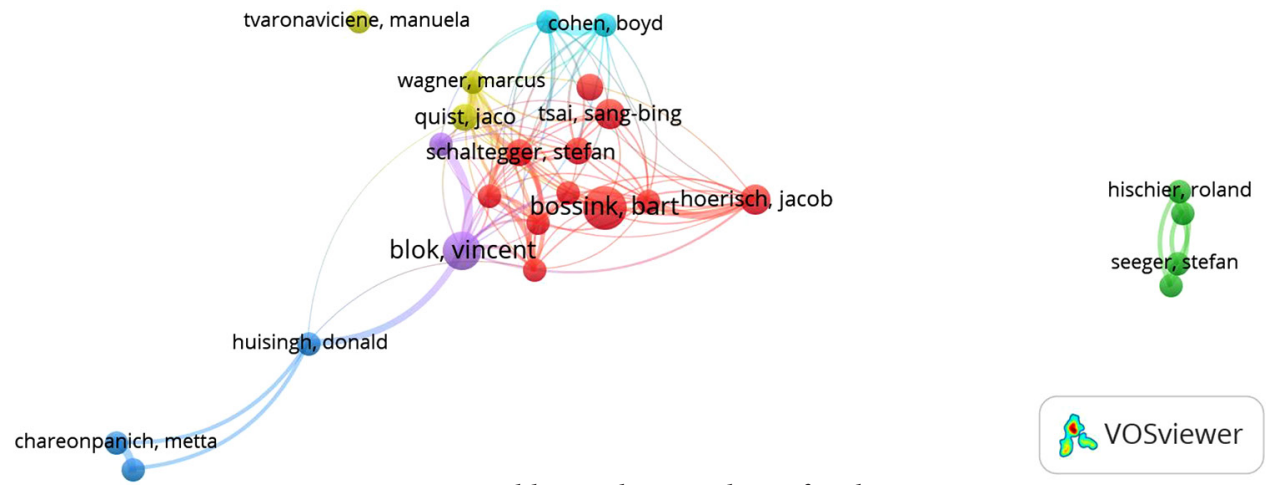

Figure 7. Bibliographic coupling of authors 




Figure 8. Bibliographic coupling by countries

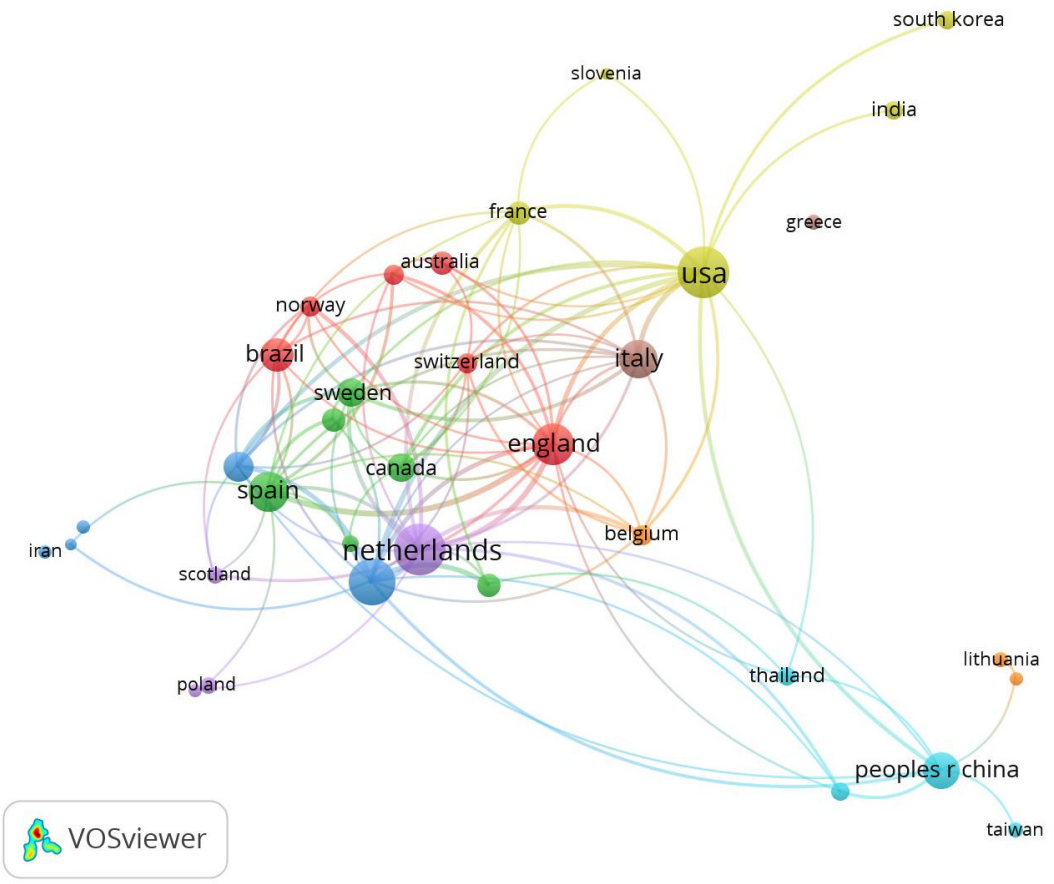

Figure 9. Co-authorship by countries 
graphic coupling, the difference can be found in the connections. It is worth noting that the largest nodes mean that they are the most influential countries, in this case the Netherlands, Germany, England, the USA and Spain. The relationship lines represent the cooperation between the countries. This figure was made with a threshold of at least five documents and 100 connections.

Finally, by reviewing the main keywords, Figure 10 displays the main keywords, taking into account a threshold of five occurrences and the 100 most representative connections. The words that stand out the most are: sustainability, sustainable innovation, sustainable entrepreneurship, innovation, entrepreneurship, sustainable development, social entrepreneurship, environmental entrepreneurship, eco-innovation and corporate social responsibility. On the other hand, Table 12 shows all the most common author keywords with their respective co-occurrences and the total strength of the connection. It is evident that the main word is Sustainability, Sustainability Innovation and Sustainability Entrepreneurship.

VOSviewer

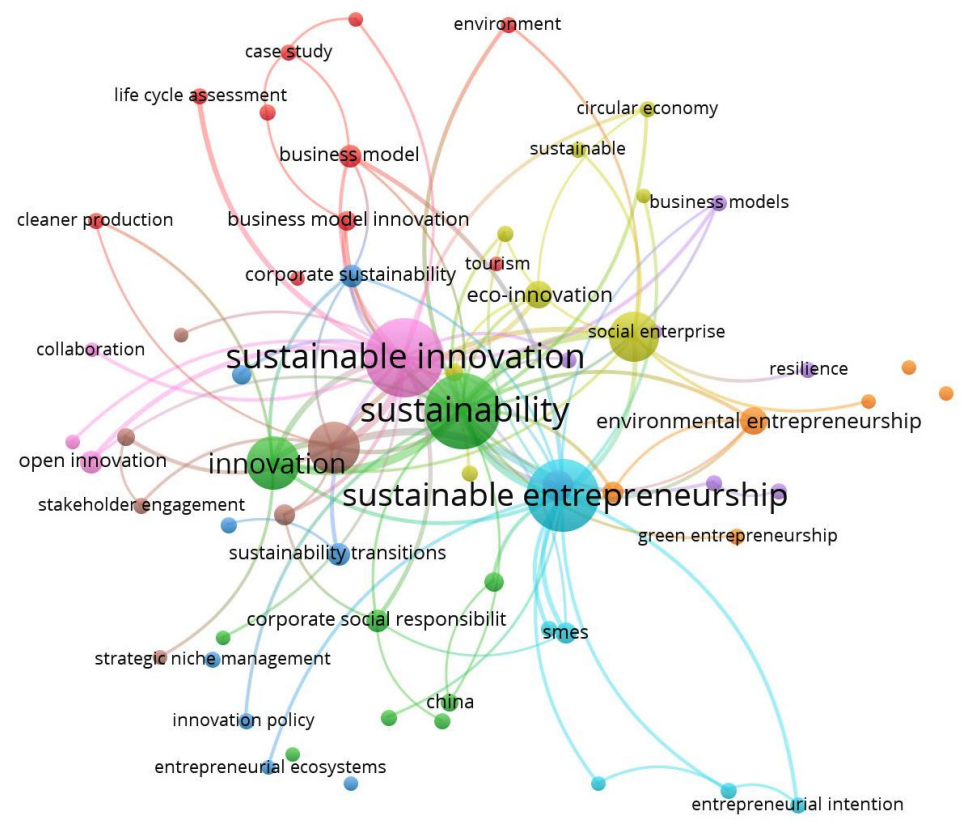

Figure 10. Co-occurrence of author keywords

Table 12. Most common author keywords (source: own elaboration)

\begin{tabular}{|c|l|c|c|}
\hline No. & \multicolumn{1}{|c|}{ Keywords } & Occurrences & TLS \\
\hline 1 & Sustainable Innovation & 138 & 87.00 \\
\hline 2 & Sustainability & 124 & 104.00 \\
\hline 3 & Sustainable Entrepreneurship & 113 & 72.00 \\
\hline 4 & Innovation & 64 & 49.00 \\
\hline 5 & Sustainable Development & 60 & 53.00 \\
\hline
\end{tabular}

Note: TLS - Total Link Strength. 


\section{Discussion}

The number of researches related to sustainable entrepreneurship has increased since 2015 on the back, firstly, that the issue of sustainability is flourishing and, secondly, since there is greater access to databases and the internet more publications can be found on the subject. While the increase can be seen in 2015, it is worth noting that, starting in 2010, the terms (with their derivatives) Entrepreneur, Innovation and Sustainability, had a greater growth. This approach indicates that the issue of sustainable entrepreneurship is becoming emerging fields of interest for researchers in different areas of knowledge, entrepreneurs, State and professionals.

Development trends on sustainable entrepreneurship have focused on reviewing how sustainable entrepreneurship relates to sustainable development, in this sense researches have focused on innovation issues, sustainable innovation and sustainable business models, among others. Likewise, there is a tendency to define what sustainable entrepreneurship is, but there is no unification of concepts, researches have been focused towards ecological, environmental and social areas. Nevertheless, there are other definitions of sustainable entrepreneurship. It is important to mention that these trends have solved problems related to environmental and social issues and how sustainable entrepreneurship contributes to the solution of these problems. They have also solved how market imperfections create opportunities for sustainable entrepreneurship.

\section{Conclusions}

This research contributes to the field of investigation since it presents the main authors and documents on the subject, as well as the main countries and journals through 2019. In conclusion the most relevant countries in publishing topics on sustainable entrepreneurship are the Netherlands, the USA, Germany, England and Spain. The authors more related to leading journals establish that the Journal of Cleaner Production and Sustainability are the most relevant. The authors with the most publications are York (USA), Blok (Netherlands), Bossink (Netherlands) and Cohen (Canada, Spain, Australia and Chile). However, it is necessary to strengthen the academic production of Latin American countries, since, as shown in Figure 9, academic production and co-authorship are very low. Equally, the documents found in their majority do not have more than 10 citations, this reflects that it is still necessary to disclose more knowledge and generate impact that it serves for future researches.

Among the future lines of research there is the possibility of a comparative sustainable entrepreneurship by countries taking into account that the main publications are in Europe. Another line is to analyze how sustainable entrepreneurship is being approached in Latin American countries and compare the results with other countries, however, this type of analysis could be carried out using other databases such as Scopus or Google Scholar, in order to have more information, because it is evidenced that Latin American countries have very few publications in the WoS on the subject, but this does not mean that they are not writing and publishing. Another line of research is to analyze how the different areas of knowledge are interwoven. In this sense, it would be of great value for researchers to understand what is 
being researched and where research is going in each field of knowledge, taking into account that in our analysis we presented areas associated with business/management, environment, engineering, among others. Finally, a research problem was identified that has not been solved and that is that there is no index that measures sustainable entrepreneurship, this could be a very interesting line of research.

\section{Funding}

This research received no external funding.

\section{Author contributions}

All authors have contributed equally in this work.

\section{Disclosure statement}

The authors declare no conflict of interest.

\section{References}

Albort-Morant, G., Henseler, J., Leal-Millán, A., \& Cepeda-Carrión, G. (2017). Mapping the field: A bibliometric analysis of green innovation. Sustainability, 9(6), 1-15. https://doi.org/10.3390/su9061011

Alonso, S., Cabrerizo, F. J., Herrera-Viedma, E., \& Herrera, F. (2009). h-Index: A review focused in its variants, computation and standardization for different scientific fields. Journal of Informetrics, 3(4), 273-289. https://doi.org/10.1016/j.joi.2009.04.001

Belz, F. M., \& Binder, J. K. (2017). Sustainable Entrepreneurship: A Convergent Process Model. Business Strategy and the Environment, 26(1), 1-17. https://doi.org/10.1002/bse.1887

Betáková, J., Havierniková, K., Okręglicka, M., Mynarzova, M., \& Magda, R. (2020). The role of universities in supporting entrepreneurial intentions of students toward sustainable entrepreneurship. Entrepreneurship and Sustainability Issues, 8(1), 573-589. https://doi.org/10.9770/jesi.2020.8.1(40)

Biemans, W., Griffin, A., \& Moenaert, R. (2007). Twenty years of the Journal of Product Innovation Management: History, participants, and knowledge stock and flows. Journal of Product Innovation Management, 24(3), 193-213. https://doi.org/10.1111/j.1540-5885.2007.00245.x

Bocken, N. M. P. (2015). Sustainable venture capital - Catalyst for sustainable start-up success? Journal of Cleaner Production, 108, 647-658. https://doi.org/10.1016/j.jclepro.2015.05.079

Bonilla, C. A., Merigó, J. M., \& Torres-Abad, C. (2015). Economics in Latin America: a bibliometric analysis. Scientometrics, 105(2), 1239-1252. https://doi.org/10.1007/s11192-015-1747-7

Boons, F., \& Lüdeke-Freund, F. (2013). Business models for sustainable innovation: State-of-the-art and steps towards a research agenda. Journal of Cleaner Production, 45, 9-19. https://doi.org/10.1016/j.jclepro.2012.07.007

Bos-Brouwers, H. E. J. (2010). Corporate sustainability and innovation in SMEs: Evidence of themes and activities in practice. Business Strategy and the Environment, 19(7), 417-435. https://doi.org/10.1002/bse.652

Boyack, K. W., \& Klavans, R. (2010). Co-Citation Analysis, Bibliographic Coupling, and Direct Citation: Which Citation Approach Represents the Research Front Most Accurately? Journal of the American Society for Information Science and Technology, 12(61), 2389-2404. 
Broadus, R. N. (1987). Toward a definition of "bibliometrics." Scientometrics, 12(5-6), 373-379. https://doi.org/10.1007/BF02016680

Cancino, C. A., Merigó, J. M., Coronado, F., Dessouky, Y., \& Dessouky, M. (2017). Forty years of Computers \& Industrial Engineering: A bibliometric analysis. Computers and Industrial Engineering, 113, 614-629. https://doi.org/10.1016/j.cie.2017.08.033

Cancino, C. A., Merigó, J. M., Torres, J. P., \& Diaz, D. (2018). A bibliometric analysis of venture capital research. Journal of Economics, Finance and Administrative Science, 23(45), 182-195. https://doi.org/10.1108/JEFAS-01-2018-0016

Cohen, B., \& Winn, M. I. (2007). Market imperfections, opportunity and sustainable entrepreneurship. Journal of Business Venturing, 22(1), 29-49. https://doi.org/10.1016/j.jbusvent.2004.12.001

Dean, T. J., \& McMullen, J. S. (2007). Toward a theory of sustainable entrepreneurship: Reducing environmental degradation through entrepreneurial action. Journal of Business Venturing, 22(1), 50-76. https://doi.org/10.1016/j.jbusvent.2005.09.003

Demirel, P., Li, Q. C., Rentocchini, F., \& Tamvada, J. P. (2019). Born to be green: new insights into the economics and management of green entrepreneurship. Small Business Economics, 52(4), 759-771. https://doi.org/10.1007/s11187-017-9933-z

Eller, F. J., Gielnik, M. M., Wimmer, H., Thölke, C., Holzapfel, S., Tegtmeier, S., \& Halberstadt, J. (2020). Identifying business opportunities for sustainable development: Longitudinal and experimental evidence contributing to the field of sustainable entrepreneurship. Business Strategy and the Environment, 29(3), 1387-1403. https://doi.org/10.1002/bse.2439

Fahimnia, B., Sarkis, J., \& Davarzani, H. (2015). Green supply chain management: A review and bibliometric analysis. International Journal of Production Economics, 162, 101-114. https://doi.org/10.1016/j.ijpe.2015.01.003

Fichter, K., \& Tiemann, I. (2020). Impacts of promoting sustainable entrepreneurship in generic business plan competitions. Journal of Cleaner Production, 267, 122076. https://doi.org/10.1016/j.jclepro.2020.122076

Foxon, T., \& Pearson, P. (2008). Overcoming barriers to innovation and diffusion of cleaner technologies: some features of a sustainable innovation policy regime. Journal of Cleaner Production, 16(1(suppl. 1)), S148-S161. https://doi.org/10.1016/j.jclepro.2007.10.011

Frank Boons, Carlos Montalvo, Jaco Quist, \& Marcus Wagner. (2013). Sustainable innovation, business models and economic performance: an overview. Journal of Cleaner Production, 45, 1-8. https://doi.org/10.1016/j.jclepro.2012.08.013

Gast, J., Gundolf, K., \& Cesinger, B. (2017). Doing business in a green way: A systematic review of the ecological sustainability entrepreneurship literature and future research directions. Journal of Cleaner Production, 147, 44-56. https://doi.org/10.1016/j.jclepro.2017.01.065

Glänzel, W., Schubert, A., \& Czerwon, H. . (1999). A bibliometric analysis of international scientific cooperation of the European Union (1985-1995). Scientometrics, 45(2), 185.

https://doi.org/10.1007/BF02458432

Halberstadt, J., Schank, C., Euler, M., \& Harms, R. (2019). Learning sustainability entrepreneurship by doing: Providing a lecturer-oriented service learning framework. Sustainability (Switzerland), 11(5). https://doi.org/10.3390/su11051217

Hellström, T. (2007). Dimensions of environmentally sustainable Innovation: The structure of ecoinnovation concepts. Sustainable Development, 15(3), 148-159. https://doi.org/10.1002/sd.309

Hirsch, J. E. (2005). An index to quantify an individual's scientific research output. Proceedings of the National Academy of Sciences of the United States of America, 102(46), 16569-16572. https://doi.org/10.1061/41064(358)182

Hockerts, K., \& Wüstenhagen, R. (2010). Greening Goliaths versus emerging Davids - Theorizing about the role of incumbents and new entrants in sustainable entrepreneurship. Journal of Business Venturing, 25(5), 481-492. https://doi.org/10.1016/j.jbusvent.2009.07.005 
Kessler, M. M. (1963). Bibliographic coupling between scientific articles. American Documentation, 24, 123-131.

Klewitz, J., \& Hansen, E. G. (2014). Sustainability-oriented innovation of SMEs: A systematic review. Journal of Cleaner Production, 65, 57-75. https://doi.org/10.1016/j.jclepro.2013.07.017

Kuckertz, A., \& Wagner, M. (2010). The influence of sustainability orientation on entrepreneurial intentions - Investigating the role of business experience. Journal of Business Venturing, 25(5), 524-539. https://doi.org/10.1016/j.jbusvent.2009.09.001

Leach, M., Rockström, J., Raskin, P., Scoones, I., Stirling, A. C., Smith, A., Thompson, J., Millstone, E., Ely, A., Arond, E., Folke, C., \& Olsson, P. (2012). Transforming innovation for sustainability. Ecology and Society, 17(2). https://doi.org/10.5751/ES-04933-170211

Liao, H., Tang, M., Luo, L., Li, C., Chiclana, F., \& Zeng, X. J. (2018). A bibliometric analysis and visualization of medical big data research. Sustainability, 10(1), 1-18.

https://doi.org/10.3390/su10010166

Merigó, J. M., Gil-Lafuente, A. M., \& Yager, R. R. (2015). An overview of fuzzy research with bibliometric indicators. Applied Soft Computing Journal, 27, 420-433. https://doi.org/10.1016/j.asoc.2014.10.035

Merigó, J. M., Pedrycz, W., Weber, R., \& de la Sotta, C. (2018). Fifty years of Information Sciences: A bibliometric overview. Information Sciences, 432, 245-268. https://doi.org/10.1016/j.ins.2017.11.054

Merigó, J. M., \& Yang, J. B. (2017). Accounting Research: A Bibliometric Analysis. Australian Accounting Review, 27(1), 71-100. https://doi.org/10.1111/auar.12109

Muñoz, P., \& Cohen, B. (2018). Sustainable Entrepreneurship Research: Taking Stock and looking ahead. Business Strategy and the Environment, 27(3), 300-322. https://doi.org/10.1002/bse.2000

Neck, H., Brush, C., \& Allen, E. (2009). The landscape of social entrepreneurship. Business Horizons, 52(1), 13-19. https://doi.org/10.1016/j.bushor.2008.09.002

Nill, J., \& Kemp, R. (2009). Evolutionary approaches for sustainable innovation policies: From niche to paradigm? Research Policy, 38(4), 668-680. https://doi.org/10.1016/j.respol.2009.01.011

Ozaki, R. (2011). Adopting sustainable innovation: What makes consumers sign up to green electricity? Business Strategy and the Environment, 20(1), 1-17. https://doi.org/10.1002/bse.650

Pacheco, D. F., Dean, T. J., \& Payne, D. S. (2010). Escaping the green prison: Entrepreneurship and the creation of opportunities for sustainable development. Journal of Business Venturing, 25(5), 464-480. https://doi.org/10.1016/j.jbusvent.2009.07.006

Pineda Ospina, D. L. (2015). Bibliometric analysis for the identification of factors of innovation in the food industry. AD-Minister, (27), 95-126. https://doi.org/10.17230/ad-minister.27.5

QSR International. (2020). NVIVO. (version 121) [Computer software]. http://www.qsrinternational. com/nvivo-spanish

Rodgers, C. (2010). Sustainable entrepreneurship in SMEs: a case study analysis. Corporate Social Responsibility and Environmental Management, 132(March), 125-132. https://doi.org/10.1002/csr.223

Schaltegger, S. (2014). A Framework for Ecopreneurship. Greener Management International, 2002(38), 45-58. https://doi.org/10.9774/gleaf.3062.2002.su.00006

Schaltegger, S., \& Wagner, M. (2011). Sustainable entrepreneurship and sustainability innovation: Categories and interactions. Business Strategy and the Environment, 20(4), 222-237. https://doi.org/10.1002/bse.682

Schiederig, T., Tietze, F., \& Herstatt, C. (2012). Green innovation in technology and innovation management - an exploratory literature review. $R$ and D Management, 42(2), 180-192.

https://doi.org/10.1111/j.1467-9310.2011.00672.x

Schot, J., \& Geels, F. W. (2008). Strategic niche management and sustainable innovation journeys: Theory, findings, research agenda, and policy. Technology Analysis and Strategic Management, 20(5), 537-554. https://doi.org/10.1080/09537320802292651 
Shepherd, D. A., \& Patzelt, H. (2011). The new field of sustainable entrepreneurship: Studying entrepreneurial action linking "What is to be sustained" with "What is to be developed." Entrepreneurship: Theory and Practice, 35(1), 137-163. https://doi.org/10.1111/j.1540-6520.2010.00426.x

Short, J. C., Ketchen, D. J., Shook, C. L., \& Ireland, R. D. (2010). The concept of "Opportunity" in entrepreneurship research: Past accomplishments and future challenges. Journal of Management, 36(1), 40-65. https://doi.org/10.1177/0149206309342746

Small, H. (1973). Co-citation in the scientific literature: A new measure of the relationship between two documents. Journal of the American Society for Information Science, 24(4), 265-269. https://doi.org/10.1002/asi.4630240406

Smith, A., Voß, J. P., \& Grin, J. (2010). Innovation studies and sustainability transitions: The allure of the multi-level perspective and its challenges. Research Policy, 39(4), 435-448. https://doi.org/10.1016/j.respol.2010.01.023

Stirling, A. (2007). A general framework for analysing diversity in science, technology and society. Journal of the Royal Society Interface, 4(15), 707-719. https://doi.org/10.1098/rsif.2007.0213

Terán-Yépez, E., Marín-Carrillo, G. M., Casado-Belmonte, M. del P., \& Capobianco-Uriarte, M. de las M. (2020). Sustainable entrepreneurship: Review of its evolution and new trends. Journal of Cleaner Production, 252, 119742. https://doi.org/10.1016/j.jclepro.2019.119742

van Eck, N. J., \& Waltman, L. (2010). Software survey: VOSviewer, a computer program for bibliometric mapping. Scientometrics, 84(2), 523-538. https://doi.org/10.1007/s11192-009-0146-3

van Eck, N. J., \& Waltman, L. (2020). VOSviewer (version 1.6.14) [Computer software]. Centre for Science and Technology Studies, Leiden University. http://www.vosviewer.com/

Varadarajan, R. (2017). Innovating for sustainability: a framework for sustainable innovations and a model of sustainable innovations orientation. Journal of the Academy of Marketing Science, 45(1), 14-36. https://doi.org/10.1007/s11747-015-0461-6

Wagner, M., Schaltegger, S., Hansen, E. G., \& Fichter, K. (2019). University-linked programmes for sustainable entrepreneurship and regional development: how and with what impact? Small Business Economics. https://doi.org/10.1007/s11187-019-00280-4

York, J. G., \& Venkataraman, S. (2010). The entrepreneur-environment nexus: Uncertainty, innovation, and allocation. Journal of Business Venturing, 25(5), 449-463. https://doi.org/10.1016/j.jbusvent.2009.07.007

Zupic, I., \& Čater, T. (2015). Bibliometric methods in management and organization. Organizational Research Methods, 18(3), 429-472. https://doi.org/10.1177/1094428114562629 